\title{
Bina Lingkungan Bagi Masyarakat Dusun Pademare Desa Sambik Elen Lombok Utara NTB Sebagai Wujud PKM Bakti Milenial
}

\author{
Lolom Evalita Hutabarat ${ }^{1}$, Candra Christanti Purnomo², Putri Rimbun Purba ${ }^{3}$ \\ ${ }^{1}$ Dosen Prodi Teknik Sipil FT Universitas Kristen Indonesia \\ ${ }^{2}$ Dosen Prodi Teknik Sipil FT Universitas Kristen Indonesia \\ ${ }^{3}$ Mahasiswa Prodi Teknik Sipil FT Universitas Kristen Indonesia \\ E-mail: lolom.hutabarat@uki.ac.id; candra.christianti@uki.ac.id; \\ putririmbunpurba0212@gmail.com
}

\begin{abstract}
Abstrak
Pandemi Covid-19 yang telah berlangsung lebih dari setahun telah berdampak pada seluruh aspek kehidupan masyarakat. Masyarakat dituntut untuk beradaptasi dengan keadaan akibat merebaknya virus yang masuk ke dalam kehidupan masyarakat. Perubahan sosial akibat kebijakan baru yang harus disesuaikan telah menimbulkan masalah baru seperti kurangnya pengunjung atau wisatawan yang datang ke sebagian besar kawasan potensi wisata di Indonesia, termasuk di Desa Pademare Sambik Elen Lombok Utara. Minimnya infrastruktur menjadi kendala utama yang dihadapi beberapa wilayah tersebut, seperti akses jalan yang belum memadai untuk akses menuju lokasi tersebut. Dalam upaya membantu pengembangan desa wisata, berbagai metode dirancang untuk mengajak mahasiswa berbagi pengalaman, mengembangkan inovasi dan ide untuk memberikan solusi berkelanjutan khususnya dalam masalah lingkungan. Perguruan Tinggi sebagai bagian dari civitas akademika berupaya melaksanakan kegiatan pengabdian kepada masyarakat melalui Lembaga Pengabdian kepada Masyarakat setingkat Universitas yang dilakukan oleh dosen sebagai nara sumber bersama dengan mahasiswa yang melakukan sosialisasi di lokasi, sesuai bidang studinya. Kegiatan Pengabdian Masyarakat Milenial bekerjasama dengan Yayasan Indonesia Millenial Connect yang berfokus pada pengelolaan sampah diharapkan dapat menciptakan lingkungan yang berkelanjutan di masa depan.
\end{abstract}

Kata Kunci: Lingkungan berkelanjutan; PKM Bakti Milenial; penanganan sampah

\begin{abstract}
The Covid-19 pandemic, which has lasted more than a year, has had an impact on all aspects of people's lives. The community is required to adapt to the situation due to the outbreak of the virus that enters people's lives. Social changes due to new policies that must be adjusted have created new problems such as the lack of visitors or tourists who come to most of the tourism potential areas in Indonesia, including in the village of Pademare Sambik Elen, North Lombok. The lack of infrastructure is the main obstacle faced by some of these areas, such as inadequate road access for access to these locations. In an effort to help the development of tourist villages, various methods are designed to invite students to share experiences, develop innovations and ideas to provide sustainable solutions, especially in environmental problems. Higher Education as part of the academic community seeks to carry out community service activities through University-level Community Service Institutions carried out by lecturers as resource persons together with students who carry out socialization at the location, according to their field of study. Millennial Community Service Activities in collaboration with the Indonesia Millenial Connect Foundation which focuses on waste management are expected to create a sustainable environment in the future.
\end{abstract}

Keywords: sustainable environment; millennial community services, garbage management 


\section{PENDAHULUAN}

Pandemi Covid-19 yang telah berlangsung setahun lamanya, telah berdampak pada segala aspek kehidupan masyarakat. Masyarakat dituntut untuk menyesuaikan keadaan dari kekuatan eksternal yang dalam hal ini adalah merebaknya virus yang masuk dalam kehidupan masyarakat. sebagai akibat dari adanya virus Covid-19 ini masyarakat mengalami perubahan sosial karena kebijakan-kebijakan baru yang harus disesuaikan, meski sebenarnya masyarakat tidak siap dengan adanya pandemi ini. Salah satu aspek kehidupan yang terdampak adalah bidang ekonomi.

Sesuai dengan Tujuan

Pembangunan Berkelanjutan atau dikenal dengan Sustainable Development Goals (SDGs) periode 2015-2030 yang merupakan kelanjutan periode 2000- 2015 (Ogbuigwe, 2019) berisi 17 tujuan (Gambar 1) dan 169 sasaran pembangunan dalam mengejar ketertinggalan pembangunan di negaranegara berkembang termasuk Indonesia terhadap negara maju (Panuluh, 2016). Indikator negara maju jika negara tersebut memenuhi kriteria yaitu (1) pendapatan per kapita tinggi diatas US\$12,375; (2) jumlahpenduduk miskin rendah; (3) angka pengangguran yang rendah; (4) tingkat kesehatan yang tinggi ditandai dengan kematian bayi dan ibu melahirkan rendah; (5) laju pendidikan dan penguasaan teknologi yang tinggi. Pada tahun 2018 Pendapatan Nasional Bruto (Gross National Income/GNI) Indonesia baru menyentuh US\$ 3.840 per kapita sehingga Indonesia masih masuk dalam kategori negara berpendapatan menengah atau middle income (Yuni, 2020).

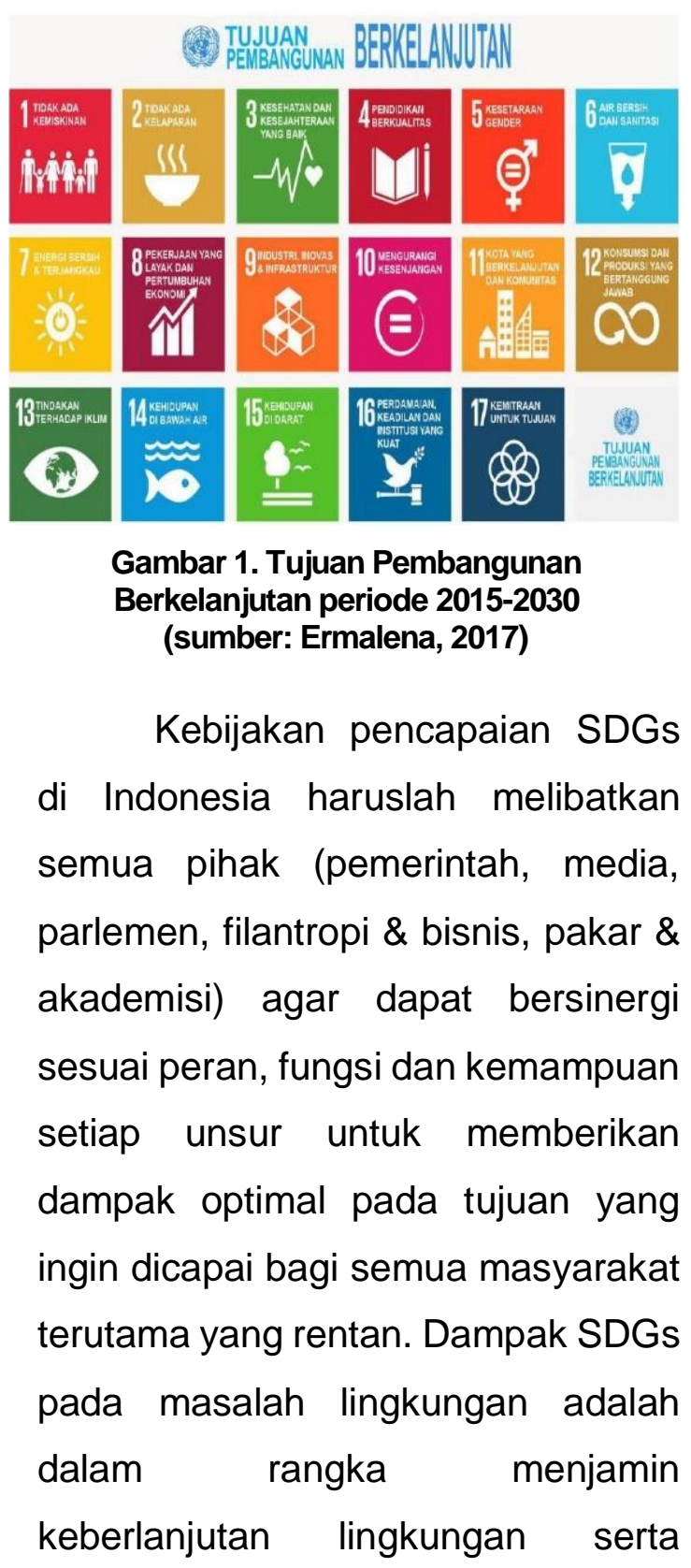


mempertinggi ketahanan terhadap bencana yang merupakan pilar pembangunan lingkungan yang terdiri dari 4 goals, 38 target dan 43 indikator (Ermalena, 2017), yaitu:

a) Goal 12: Konsumsi dan Produksi berkelanjutan

b) Goal 13: Perubahan Iklim dan Pengurangan Resiko Bencana

c) Goal 14: Pelestarian dan Pemanfaatan Berkelanjutan Ekosistem Laut

d) Goal 15: Pelestarian dan Pemanfaatan Berkelanjutan Ekosistem Darat

Dampak pandemik Covid-19 menyebabkan Indonesia mengalami resesi ekonomi yang ditandai dengan produk domestik bruto RI pada kuartal III2020 minus mencapai $3,49 \%$ sesuai data Badan Pusat Statistik (BPS) menurut Harian Kompas tanggal 5 November 2020 (https://money.kompas.com/read/2020/11 105/111828826). Hal ini mengakibatkan pemerintah harus turun langsung memberikan bantuan atau subsidi kepada masyarakat miskin berupa bantuan biaya pendidikan dan kesehatan khususnya di daerah-daerah $3 \mathrm{~T}$ (terdepan, terluar, tertinggal) yang terlihat dari data empiris berbagai studi di beberapa wilayah Indonesia (Syafii,2018; Dike, 2017; Nawir, 2018; Gultom, 2020).

\section{METODE}

Sesuai Undang-Undang No.6 Tahun 1996 Indonesia yang memiliki 17.508 pulau. dimana baru sejumlah 16.771 pulau yang memiliki nama dan pada tertera Gasetir Nasional pada tahun 2020 (https://kkp.go.id/djpr/p4k/page/4270jumlah-pulau). Umumnya pulau-pulau tersebut mengandalkan pariwisata sebagai sumber pendapatan utamanya. Sektor pariwisata di Indonesia merupakan salah satu penyumbang pendapatan terbesar negara (devisa). Tetapi sejak pandemik Covid-19 berlangsung pendapatan dari sektor ini sangat turun bahkan usaha-usaha kecil di bidang pariwisata terancam gulung tikar seperti juga yang terjadi di desa Sambik Elen.

Desa Sambik Elen pada awalnya adalah bagian Desa Loloan yang pada tahun 2002 mengalami pemekaran wilayah menjadi wilayah Desa Loloan dan Desa Sambik Elen batas geografis:
a) Timur : kabupaten Lombok Timur
b) Selatan : hutan tutupan Rinjani
c) Barat : Desa Loloan
d) Utara : Laut Jawa

Lokasi Desa Sambik Elen cukup strategis karena berdekatan dengan Taman Nasional Gunung Rinjani yang ditetapkan sebagai salah satu kawasan konservasi di provinsi Nusa Tenggara Barat sejak tahun 2017 melalui SK 
243/KSDAE/SET/KS/A.0/6/2017 dengan luas 41.330,01 ha. Desa Senange Sambik Elen secara resmi dibuka sebagai Pintu Masuk Jalur Pendakianke Balai Taman Nasional Gunung Rinjani Resort Senaru pada tanggal 27 Mei 2021.

Lombok utara memiliki puluhan air terjun, mulai dataran sampai pegunungan di kawasan hutan Rinjani barat atau Taman Nasional Gunung Rinjani dimana satunya adalah air terjun Tiu Candi yang berada di desa Sambik Elen Kecamatan Bayan, yang merupakan obyek pariwisata yang sangat diminati di kalangan remaja seperti terlihat pada Gambar 2 berikut:
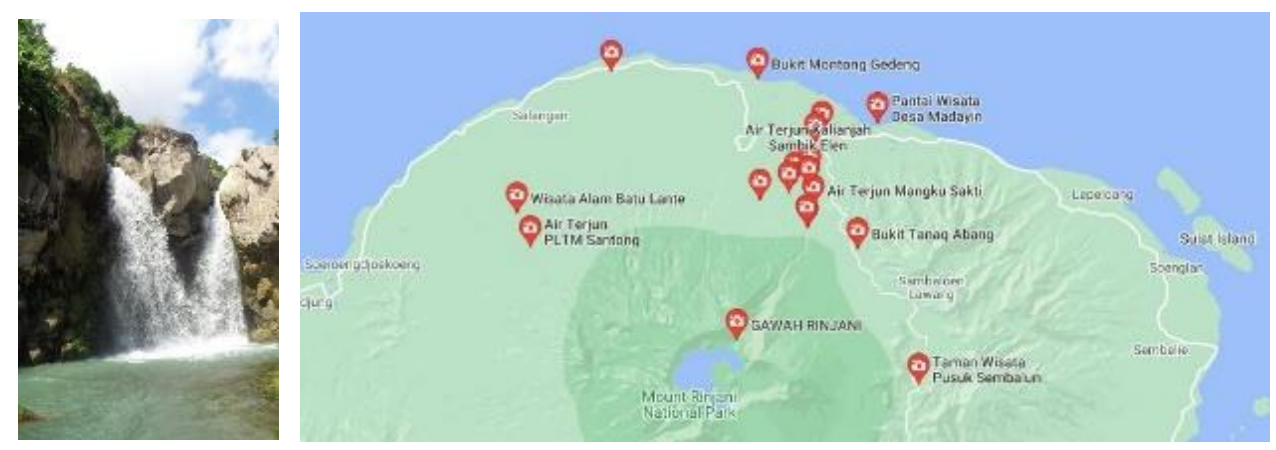

\section{Gambar 2. Air terjun Tiu Candi di Desa Sambik Elen dan Destinasi Pariwisata lainnya}

Karena itulah beberapa organisasi atau komunitas sosial (NGO) melakukan berbagai kegiatan untuk membantu memulihkan perekonomian di wilayah yang terkena dampak terbesar, termasuk juga perguruan tinggi sebagai bagian dari masyarakat akademik berupaya melakukan kegiatan pengabdian masyarakat yang dilaksanakan oleh dosen sebagai tenaga pengajar bersamasama dengan mahasiswa sesuai bidang keilmuan.

Target dari PKM ini adalah ikut berperan mengembangkan Dusun Pade Mare desa Sambik Elen, Lombok Utara, Nusa Tenggara Barat menjadi desa wisata dengan pemberdayaan masyarakat yang berkelanjutan untuk mengembangkan desanya melalui program Bakti Milineal. Bakti Milenial merupakan sebuah program yang dirancang untuk mengajak kaum muda untuk berbagi pengalaman, mengembangkan inovasi dan gagasan ide guna memberikan solusi yang berkelanjutan. Kegiatan pengabdian lintas disiplin ilmu yang terbuka untuk masyarakat umum yang dilaksanakan oleh Prodi Teknik Sipil FT UKI berupa Bina Lingkungan untuk Pengolahan dan Pemilhan Sampah dengan prinsip 3R (reduce, reuse dan recycle). Adapun metode yang akan dilakukan untuk memberikan solusi dalam permasalahan 
Volume 3, Nomor 2, Tahun 2021 Hal 643 - 652

lingkungan dapat dilihat pada Tabel 1

berikut:

Tabel 1. Metode Pemecahan Masalah Bina Lingkungan

\begin{tabular}{|c|c|c|}
\hline Permasalahan & Solusi & Metode Pelaksanaan \\
\hline $\begin{array}{l}\text { Minimnya kesadaran } \\
\text { masyarakat terhadap } \\
\text { lingkungan sekitar obyek } \\
\text { pariwisata }\end{array}$ & $\begin{array}{l}\text { Kerja Bakti } \\
\text { Lingkungan } \\
\text { Desa }\end{array}$ & $\begin{array}{l}\text { Membuat tong sampahdan } \\
\text { melibatkan partisipasi } \\
\text { masyarakat untuk menghiasnya } \\
\text { berupa perlombaan }\end{array}$ \\
\hline $\begin{array}{l}\text { Masih minimnya kesadaran } \\
\text { masyarakatmembuang } \\
\text { sampah }\end{array}$ & $\begin{array}{l}\text { Pemilahan dan } \\
\text { Pengolahan } \\
\text { Sampah }\end{array}$ & $\begin{array}{l}\text { Memberikan sosialisasidan } \\
\text { pelatihan pemilahan dan } \\
\text { pengolahan sampah kepada } \\
\text { masyarakat }\end{array}$ \\
\hline $\begin{array}{l}\text { Membuat masyarakat } \\
\text { mandiri pangan }\end{array}$ & $\begin{array}{l}\text { Pembuatan } \\
\text { Pupuk Kompos }\end{array}$ & $\begin{array}{l}\text { Membuat pupuk kompos dari } \\
\text { kotoran ternak ataupun sampah } \\
\text { alam dari daun-daun dan } \\
\text { tanaman }\end{array}$ \\
\hline $\begin{array}{l}\text { Memberikan keterampilan } \\
\text { kepadamasyarakat untuk } \\
\text { mendukung pariwisata }\end{array}$ & $\begin{array}{l}\text { Pembuatan } \\
\text { Kerajinan Dari } \\
\text { Sampah Plastik }\end{array}$ & $\begin{array}{l}\text { Membuat program pelatihan bagi } \\
\text { masyarakat dengan keterampilan } \\
\text { umumpembuatan barang- } \\
\text { barang dari sampah plastik }\end{array}$ \\
\hline
\end{tabular}

Sampah menjadi persoalan umum disetiap daerah, karena semakin banyaknya permukiman akan berdampak pada semakin banyak pula sampah rumah tangga yang dihasilkan. Kecenderungan pola perilaku masyarakat membuang sampah sembarangan dengan pemikiran hal tersebut dilakukan hanya sesekali, namun berakibat pada dampak yang ditimbulkan. Kegiatan bersih-bersih lingkungan perlu dilakukan secara berkala untuk memberikan pemahaman pada masyarakat desa agar menjaga lingkungan dengan membuang sampah pada tempatnya.

Persoalan mengenai sampah rumah tangga seringkali menimbulkan pencemaran lingkungan. Kurangnya edukasi pada masyarakat mengenai dampak yang ditimbulkan dari sampah dan kurangnya edukasi mengenai pengelolahan sampah membuat warga seringkali menyepelekan hal yang mempunyai dampak yang bisa menimpa pada warga itu sendiri. Sehingga perlu sosialisasi pengelolahan sampah rumah 
tangga dengan pemilahan sampah yang agar dapat di daur ulang.

Selain itu mata pencaharian sebagian besar masyarakat desa yang merupakan peternak dan petani, bisa menjadi simbiosis mutualisme. Peternak yang setiap hari membersihkan kotoran hewan sementara petani membutuhkan pupuk untuk tanaman di ladang dapat memanfaatkan limbah kotoran ternak. Hal yang perlu dilakukan adalah membuat pupuk kompos yang dapat dikelola oleh warga setempat.

Berbagai macam sampah yang ada disekitar kita mulai dari yang mudah terurai hingga sampah yang membutuhkan waktu beratus tahun untuk terurai perlu dilolah sehingga dapat memberikan nilai jual. Hal yang dapat dilakukan adalah dengan mendaur ulang sampah menjadi suatu kerajinan yang bermanfaat dari sampah plastik dan dapat dijual.

\section{HASIL DAN PEMBAHASAN}

Kegiatan Bina Lingkungan di Dusun Pademare, Desa Sambiik Elen, Kec.
Bayan, Lombok Utara, NTB dilaksanakan pada tanggal 20 sampai 30 Agustus 2021. Kegiatan yang dilaksanakan dapat dilihat pada Tabel 2. Kegiatan Bina Lingkungan ini diikuti oleh sebanyak kurang lebih 25 warga dan 10 generasi muda.

Untuk mengevaluasi tingkat pemahaman warga dan pemuda-pemudi dusun Pademare terhadap isi materi sosialisasi, maka diberikan beberapa pertanyaan terkait isi materi sosialisasi dan warga dipersilahkan untuk menjawab. Warga yang berhasil menjawab pertanyaan dengan benar diberikan door prize sebagai tanda apresiasi.

Dari hasil sosialisasi, warga dan generasi muda dapat memahami materi yang disampaikan, yaitu cara memilah sampah serta cara membuat pupuk kompos. Di akhir sosialisasi di berikan waktu tanya jawab dan games tentang pemilahan dan juga pembuatan pupuk kompos

Tabel 2. Program dan Aktifitas Bina Lingkungan

\section{Program}

\begin{tabular}{|c|c|}
\hline Program & Aktifitas \\
\hline $\begin{array}{l}\text { Sosialisasi pemilahan dan } \\
\text { pengolahan sampah }\end{array}$ & $\begin{array}{l}\text { 1. Perkenalan dengan warga } \\
\text { 2. Sosialisasi tentang pengertian sampah, } \\
\text { pengelompokan sampah, pemilahan sampah dan } \\
\text { pengolahan sampah } \\
\text { 3. Diskusi dan tanya jawab } \\
\text { 4. Games pemilahan sampah }\end{array}$ \\
\hline
\end{tabular}


1. Membuat tong sampah dari ember yang besar

2. Membuat tulisan sesuai dengan jenis tong

Pembuatan tong sampah sampah yang akan di buat

3. Meletakkan nya di tempat umum, seperti di depan mushola yang ada di dusun.

1. Perkenalan dan salam pembuka kepada pemuda

Lomba membuat dan menghias tong sampah dari botol plastik dan pemudi dusun Pademare, Desa Sambik Elen, Kec Bayan, Lombok Utara, NTB

2. Menjelaskan aturan dan ketentuan lomba.

3. Memberi alat dan bahan untuk lomba.

4. Memberi hadiah bagi pemenang lomba

1. Perkenalan dan salam pembuka kepada warga dusun Pademare, Desa Sambik Elen, Kec Bayan, Lombok Utara, NTB yang merupakan sasaran utama dari kegiatan ini.

2. Penyuluhan atau sosialisasi pengertia pupuk Sosialisasi dan pembuatan pupuk kompos kompos, mafaat dan cara pembuatan pupuk kompos

3. Mempraktikkan cara pembuatan pupuk kompos

4. Sesi diskusi atau tanya jawab dengan warga yang mengikuti sosialisasi

5. Pemberian hadiah kepada warga yang bisa menjawab pertanyaan dari pemateri dan MC.

1. Mengundang seluruh warga dan volunteer agar ikut kerja bakti.

Kerja bakti lingkungan dusun

2. Menyapu dan memangkas rumput dan ada di pinggir jalan dusun

3. Membersihkan parit yang penuh dengan dedaunan kering

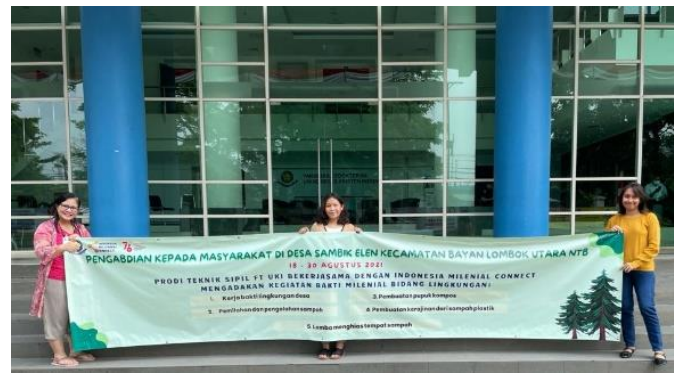

Gambar 3. Tim PKM Bakti Milenial Lombok Sebelum ke Lapangan

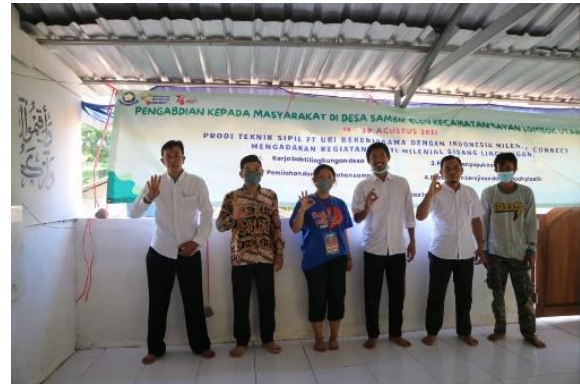

Gambar 4. Sosialisasi pemilahan dan pengolahan sampah 


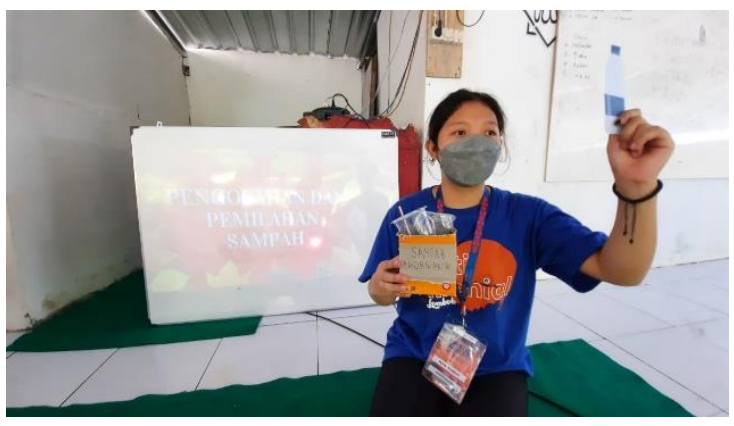

Gambar 5. Games pemilahan dan pengolahan sampah

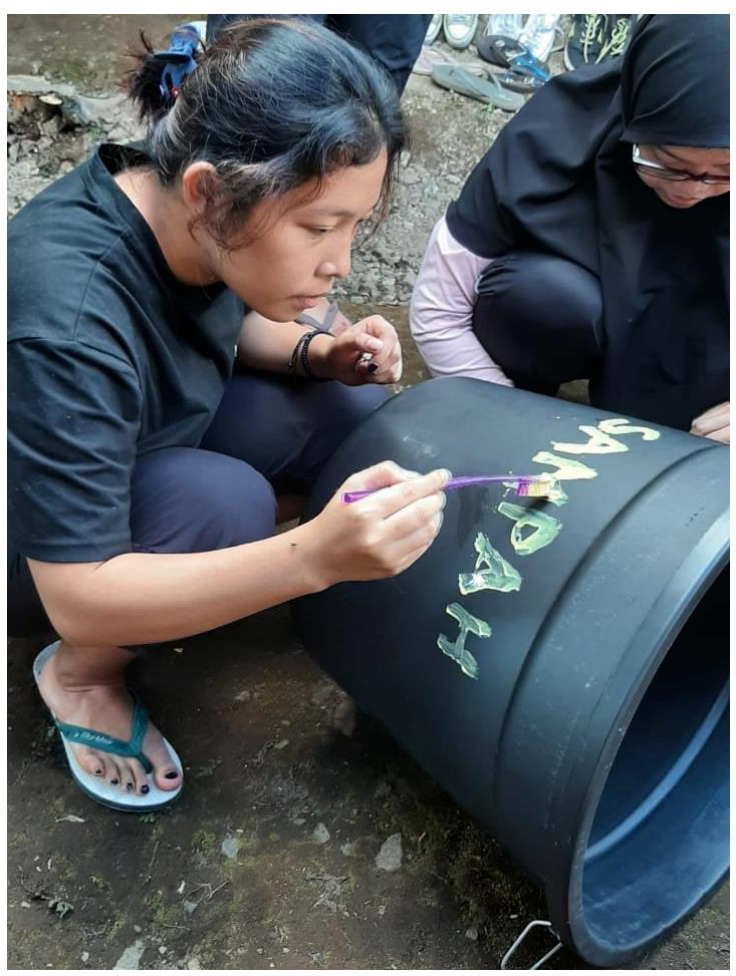

Gambar 7. Pembuatan tong sampah

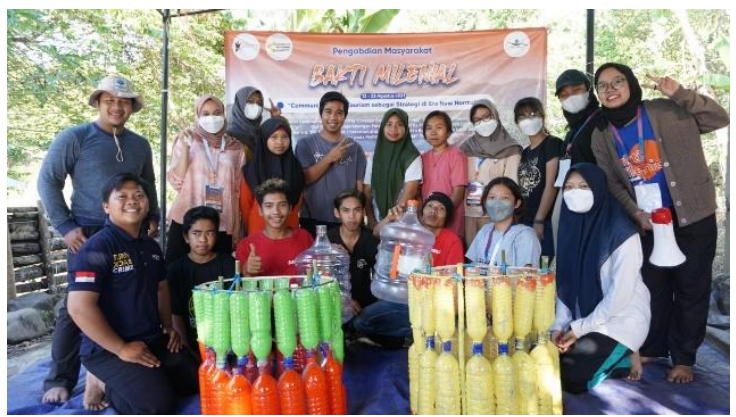

Gambar 9. Lomba daur ulang sampah dari botol plastik

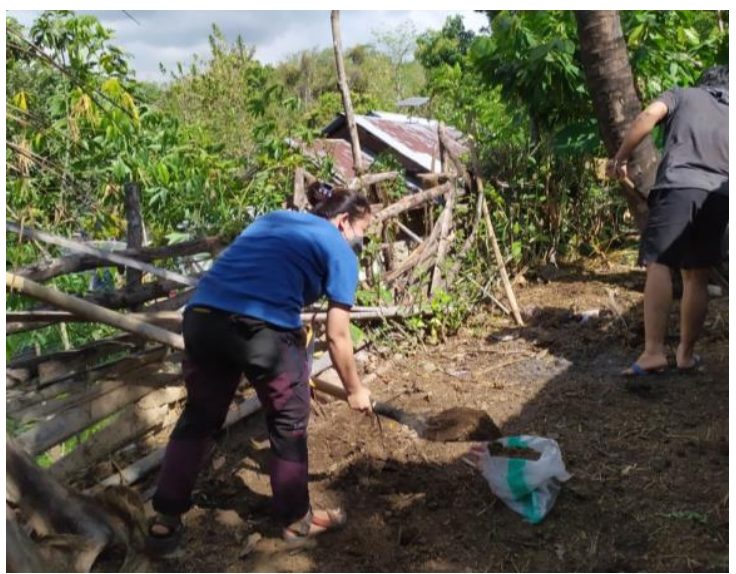

Gambar 6 Pembuatan pupuk kompos

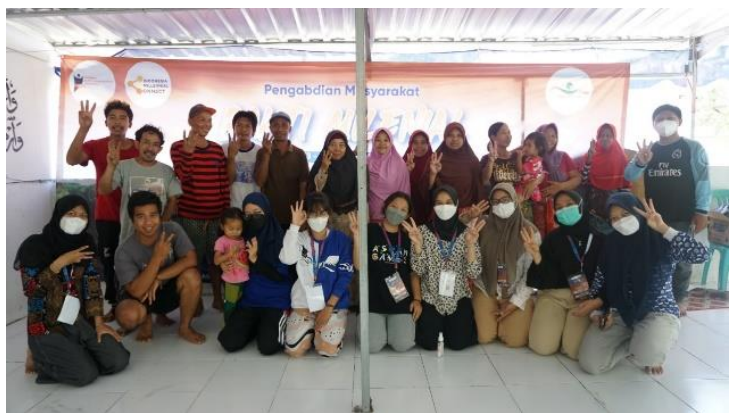

Gambar 8. Sosialisasi dan pembuatan pupuk kompos

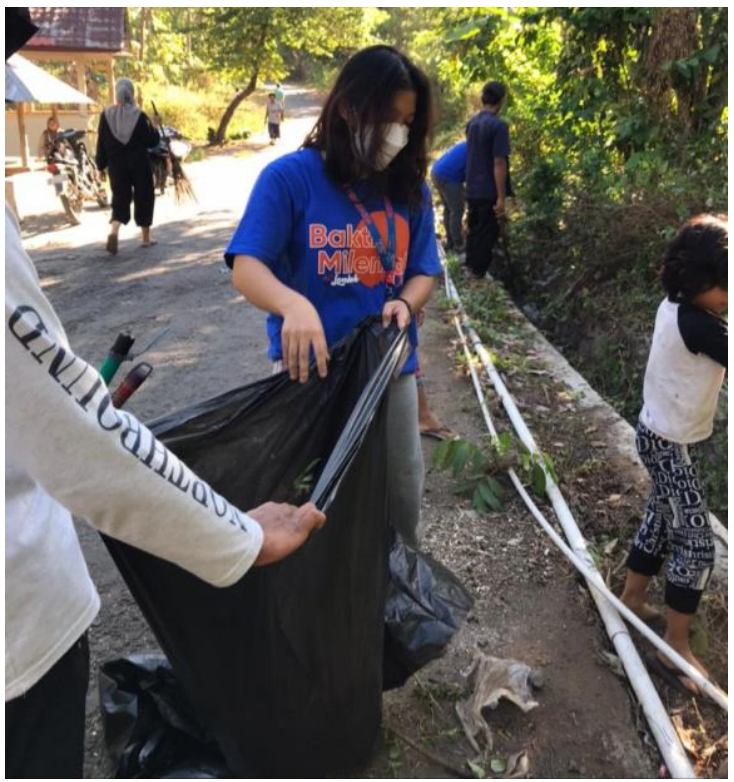

Gambar 10. Kerja Bakti Lingkungan Desa 
KESIMPULAN

Kegiatan pengabdian kepada masyarakat mengenai sosialisasi pemilahan dan pengolahan sampah di Dusun Pademare, Desa Sambik Elen, Kec Bayan, Lombok Utara, NTB, berjalan dengan baik, warga memahami dengan baik dan dapat langsung mempraktekkan pemilahan sampah. Selain itu warga pun sangat antusias mengikuti sosialisasi dan pembuatan pupuk kompos serta melihat langsung cara pembuatan pupuk kompos dengan benar.

Kegiatan pembuatan tempat sampah juga berjalan dengan baik dan hasilnya sudah di letakkan di tempat umum seperti di depan mushola. Antusiasme masyarakat saat mengikuti sosialisasi pemilahan dan pengolahan sampah terlihat dari pertanyaan yang dilontarkan kepada penceramah tentang pembuatan pupuk kompos.

\section{SARAN}

Kegiatan penyuluhan dapat berlanjut dengan pemberian materi lainnya terkait pengelolaan dan pemanfaatan daur ulang sampah. Pihak pemerintas dinas Lingkungan hidup juga mengharapkan adanya kegiatan yang berkelanjutan sehingga semakin dapat meningkatkan pengetahuan dan kesadaran warga terhadap sampah. Selain itu juga diperlukan campur tangan perangkat desa untuk selalu mengingatkan warga agar memilah sampah dan mengolah kotoran ternak dengan membuat pupuk kompos yang bernilai jual.

\section{UCAPAN TERIMA KASIH}

Ucapan terimakasih kepada mitra kerjasama prodi Sipil FT UKI yaitu Indonesia Millenial Connect yang sudah menginisiasi kegiatan PKM Bakti Milineal serta perangkat dusun Pade Mare desa Sambik Elen Kecamatan Bayan Lombok Utara.

\section{REFERENSI}

Ermalena, M. H. S., \& RI, W. (2017). Indikator Kesehatan SDGs di Indonesia. The 4thICTOH,

Dike, D. (2017). Pendidikan multikultural sekolah dasar di wilayah 3T. Jurnal Pendidikan Dasar Perkhasa: Jurnal Penelitian Pendidikan Dasar, 3(1), 277-287.

Gultom, J. M. P. (2020). Transformasi SDM Di Wilayah 3T: Implementasi Gerakan Filantropi Berbasis Misi Mahasiwa STT Real Batam.

Nawir, D., \& Zultan, A. (2018). Pemberdayaan masyarakat wilayah 3T (Terdepan, terluar, Tertinggal) di Kecamatan Sebatik Barat Kabupaten Nunukan melalui revolusi mental dalam 
mewujudkan Indonesia Bersih dan Indonesia Bersatu. Jurnal Pengabdian Masyarakat Borneo, 2(1), 44-50.

Ogbuigwe, A. (2019). Writing from the Future: The UN SDGs (2015-2030). Sustainability: The Journal of Record, 12(2), 50-52.

Panuluh, S., \& Fitri, M. R. (2016). Perkembangan pelaksanaan sustainable development goals (SDGs) di Indonesia. Biefing Paper, 2, 1-25.

Syafii, A. (2018). Perluasan dan pemerataan akses kependidikan daerah 3T (terdepan, terluar, tertinggal). Dirasat: Jurnal Manajemen dan Pendidikan Islam, 4(2), 153-171. Jakarta.

Yuni, R., Putra, P. D., \& Hutabarat, D. L. (2020). Sinergi Indonesia Menuju Negara Maju. Prosiding Webinar Fakultas Ekonomi Unimed "Strategi Dunia Usaha Menyikapi Status Indonesia Sebagai Negara Maju: Pra dan Pasca Covid-19", 35-42.

https://money.kompas.com/read/2020/ $\underline{11 / 05 / 111828826}$

https://kkp.go.id/djprl/p4k/page/4270jumlah-pulau 